\title{
Global Tourism and Language Learning: the Study Abroad Sector ${ }^{*}$
}

\author{
Andrea Salazzaro**
}

\begin{abstract}
Over the years, the globalisation of tourism has seen new players entering in the competition arena. The competition in the industry is high with offers of many products and travel experiences. The buyer decision is mostly influenced by the experience needed in a specific moment of the life. Audiences can be grouped in bubbles formed by niches of customers with same needs and intentions. The audience in the bubbles is temporary and the movement from a bubble to another depends by the needs at a specific stage of their life. In the last decade, we have observed an increase in the demand from people wishing to learn a foreign language, as a result there has been a corresponding increase in demand for holidays which include intensive language courses. A new profile of tourist is nowadays active and the tourism industry has seen the entrance of strong competitors that can offer a leisure product with a surplus: the language learning. The paper gives an overview of the dynamics of the sector and how it contributes to the growth of the global tourism industry.
\end{abstract}

Keywords: Global Tourism; Management; Global Markets; Digital Marketing; Study Abroad; Language Learning; International Students

\section{Tourism, Globalisation and Multi-channel Communication}

In recent decades the world has seen an increase in the movement of people who travel around the world for leisure. This increase in numbers in the travel and tourism industry is related to globalisation and technological advancement (Brondoni, 2016) and affects several industries. Airline alliances, hotel chains, online tour operators, search engines for comparisons and independent websites for sharing accommodations have all impacted positively the tourism industry.

Companies in the industry target their audiences using a multichannel approach including online and offline communication campaigns. Even if the "traditional" communication channels (magazines, billboards, tv and radio advertisement, etc.) have their impact in the decision process, digital marketing begins of crucial importance for companies in the sector due to the change of the travellers' profile in the recent years.

\footnotetext{
${ }^{*}$ Invited Article

** Marketing Manager Southern Europe and Africa, Kaplan International English (andrea.salazzaro@kaplan.com)
} Symphonya. Emerging Issues in Management (symphonya.unimib.it), 3, 113-121. 
The new traveller, tourist or holiday maker, seen with no difference for the sake of this article, have changed the way of accessing to information, using the web as the place where they can familiarize with the offers and get basic and complex information about the whole trip.

The platforms where information can be found are the field where competition begins. Companies adopt a multichannel strategy for reaching their audience and bring it to their website and landing pages as end of the funnel. Due to high competition and overload of information users are bombarded in their everyday life, companies activate a targeted communication to reach the right audience.

To reach the right audience and bring it at the end of the funnel, marketers use different tools and channels. Google network and social media advertising can be seen nowadays as 'classic digital tools' where companies can reach the target audience knowing their profile, interests and targeting high demand keywords. New channels have emerged in the last decade seeing 'influencers' who partner with companies or voluntary push the products.

An 'influencer' can be any person followed, trusted and imitated by a community. It can be a professional blogger, youtuber, etc. Influencers are often commissioned by companies to create marketing content (articles, videos, social activities, etc.) where to place the company product into. These are also individuals who share their experiences on social media and their profile is followed by people with same interests. Another typology of influencers are websites for reviews and recommendations. Recommendations and reviews are today among the most powerful tools that bring business to companies in the tourism industry. These influencers thus play a crucial role in the tourism industry as their shared experience has a consistent impact on the buyer decision.

In addition, competition in the industry is high and mostly linked to the intention of the audience, the kind of break needed in a specific moment of the customer's life. Audiences can be grouped in bubbles formed by niches of customers with same needs and intentions. The audience in the bubbles is temporary and the movement from a bubble to another depends on the stage of their life.

$\square$ Providers of five stars full packages in beach resorts are direct competitors as the niche of people interested in that kind of experience can be grouped by their intention (e.g. family experience, relax, break from the usual life). The intention is volatile and related to a specific moment in life. The same customer can decide to experience different holidays in a different stage such as adventure-type holidays or educational trips.

'Push communication' is another crucial aspect for companies in tourism. Working on the latent intentions of the audience brings business in this highcompetitive sector. The key to bring business is related to the message of what the customer can get from the trip. The numbers of day in a year are limited and travellers have to choose among plenty offers.

The competitors' arena in the industry is wide, and one of the new players who is taking market share, especially among teenagers, university students and young professionals, is the study languages abroad sector, where customers can unite their need of travel with a learning experience. 


\section{New Players and New Customer Profiles in Global Tourism}

Globalisation has affected all sectors and the spill over of boundaries has brought new needs for everybody. The knowledge of foreign languages to be competitive in the job market and be attractive for international companies is one of these.

English has been appointed as the universal language and for this reason the motivation of learning this language has stood out among the others. While learning a new language is important, English is nowadays the most requested language in the world. It is estimated that $61 \%$ of the people travelling abroad to learn a language choose English (Icef Monitor, 2016).

Learning English is a subject introduced in the school systems from the primary schools to university. Pupils can also improve their languages skills with extra curricula activities, mostly related to attending courses in specialized English schools in their home countries and with online learning tools.

Another way to learn a foreign language is the attending intensive language courses ('full immersion') in those countries in which the language of interest is spoken, where the process of learning speeds up due to the constant use of the language. Around the concept of 'full immersion', in the last decade companies found the potential for the development of the market and covered the scarcity of offer with new products that join the travel and education industry.

This has increased the offer in this market which new players in the tourism industry have covered the scarcity of offer with new products that join the travel and education industry and consists in bundle of services offered as a package. A new profile of tourist has been created and the tourism industry has seen the entrance of strong competitors that can offer the same leisure product with a surplus: the language learning.

\subsection{Study English Abroad: The Bundle of Products}

The increase in demand of people who need to learn English and the growing trend of people who travel for leisure have merged in a new concept of holidays abroad.

This new formula of holiday has created a new audience targeted by highly competitive small companies. In fact, this sector has many players organized in alliances, horizontal and vertical partnerships (Arrigo, 2012), and supported by specialized tour operators and travel agencies that have added this product to their catalogues. The main product offered consists in a bundle containing language course, accommodation, and extra activities. A full package includes a return journey, insurance, meals and city passes for public transports.

Due to the complexity of the products, many companies and private subjects are involved in the full offer. The subjects involved in the bundle can be split into categories: course providers, accommodation suppliers and local agencies.

\subsubsection{The Course Providers}

The course providers are the companies that offer the main product and are the schools' owners. There are few big competitors in the market who own a network of schools and a small number of independent schools. These schools are localised 
in main cities in which students from all around the world can attend. The competition is based on the quality of the structures, the learning methods, the range of products offered, and the full experience the company delivers to students. The companies are usually part of large educational groups and extend their network with the creation of brand new schools or acquisition of independent schools that are then transformed to follow the company standards.

$\square$ With over 75 years of experience, Kaplan International English (KIE) is trusted by students learning English at one of 41 Kaplan International schools located in eight countries around the world. KIE is part of Kaplan, Inc. that now has 31,000 employees in 600 locations worldwide. The group reaches more than one million students around the globe through a various branches of the company (www. kaplaninternational.com).

The course providers as KIE are focused in the offer of learning programs and innovation is the key of the success (Brondoni, 2014). Innovation is based on a market-driven approach (Brondoni, 2008; Arrigo, 2009) where companies respond to market's needs creating products better and faster than competitors. After a new product is launched the trend is to fast imitate the competitors (Baradello, Salazzaro, 2014). Continuous improvements in the learning system, the teaching methodology and the gamma of products offered are the key elements that make the company standing out from others.

$K+$ is the KIE's exclusive English language learning system. Designed by experts, it helps to maximize learning by embracing technology as a teaching and learning tool. The innovative materials work together to promote learning in class, on the move, or at home with access on internet.

The exclusive blended methodology is for example one of the distinctive characters that makes Kaplan different in the sector and reinforces the brand equity (Brondoni, 2002) for its positioning in the market.

The schools have in place a team of employees that are manly grouped in teachers, students support and other service. Among the employees looking after other services there is usually a social organizer who deals with local agencies and an accommodation manager in charge of the network of accommodations.

\subsubsection{The Accommodations Suppliers}

The main focus for the company in the education industry is the learning system. But, if a company offer languages courses abroad, the accommodation is the second main factor that influences the buyer decision.

Companies in the sector offer manly three different kinds of accommodations to their students: rooms in student residences, shared apartments and host families.

Student residences and apartments can be property of the companies especially in key cities where there is a stable students flow. The rooms can be also acquired with a rental contract made with estate companies owners of student residences. In this case students live with other international or local university students and are more flexible in the choice of their life style abroad. 
Host families are private subjects who, on the wave of the sharing economy (Salvioni, 2016), rent rooms in their house to the educational company that continuously sends students to live with the family for a period of time that can be short or long according to the agreements. The host family business involves thousands of private subjects that share with students the local life style and habits matching the concept of a full immersion in the destination and in the language learning.

In each school the accommodations managers take care in matching suitable students and hosts. Both families and students are supported by a network of regional coordinators and counsellors who will keep in close contact through the student's stay.

To be different in this high demanding market, companies have to be innovative, offer high standard accommodations and provide extra activities to complete the experience in the language learning holiday.

\subsubsection{The Local Agencies}

Companies in the study abroad sector offer also extra activities for students. Having extra curricula activities is another pillar of the language learnings.

Usually there are dedicated employees to manage this area. Partnerships with local tourist agencies are made to offer the best deals to students. Students have the opportunity to participate to cultural and leisure activities, access tourist attractions and get discounts in local participating businesses.

Cities begun attractive for students when they are already tourist destinations offering lot of events and activities. Due to their presence in a specific destination (Codignola \& Mariani, 2017), museums and art exhibitions are few of the main attractions that benefit of the presence of language students as the visit is part of the 'full immersion' in the culture of the location offered by the schools.

When students are not at the school, they are tourists. However, tourism statistics do not take into account the study abroad sector as the profile is not classified in any tourism category and when recorded it is only the country of provenience. It is estimated that every year 2.28 million people go abroad for language study (Icef Monitor, 2016) and they participate with no doubt to the growth of local tourism agencies and businesses.

\subsection{Specialised Agencies and Tour Operators}

The companies in the sector acquire customers through three main channels: online booking engines, internal sales team and third parts.

The customers (i.e. students of the language course) are usually well educated and familiar with the on-line booking system. Websites have the function to book and pay the full trip online and customers can decide which product in the bundle they want include in their package. The language courses are mandatory because this is the core business, but all the other services are supplementary.

The main difference between booking a language course abroad and leisure trips is that the choice of the course and the access to it depends on the student level of language knowledge and its learning targets. For this reason, the booking is mostly made after talking with a consultant. In fact, sale consultants still have an important role in the whole process. Even if direct sales is still used by companies, the sector is run more from third agencies: travel agencies and big specialised companies. 
Due the growth of the study abroad sector in the travel industry, local travel agencies have included the product in their offers. Customers can now choose among leisure or study abroad products. Local travel agencies are specialised in offering trips of any kind and they act as agents for the learning provider.

Different from the travel agencies are agencies specialised in offering the study languages abroad product. These kinds of agents differentiate from the travel agencies as their brand is recognized in the market as provider of the product. There are few mayor players in the market and they are aggregator of schools. Their brand position is strong and customers perceive the product offered as it they are the owner.

Specialised agents have huge power in the market and competition is high for school's owners to be included in the agencies' offer. The system can be associated to the large retail system (Riboldazzi, 2005) where relationships, commissions and adjustments in margin allow the companies to be present in their displays with a return in visibility over the competitors' products.

\subsection{The Customer Profile in the Study Abroad Sector}

The key target group in the study languages abroad sector is 18-25 years old (Icef Monitor, 2016) but the industry is widening the target audiences and has seen a growth in young learners aged 12-17 but also $25+$ in the last years.

Decision makers are mostly parents as they pay the fees and other related expenses. Students spend time at school attending lectures and outside as a tourist or working in part-time jobs. There are countries where a visa is not necessary (e.g. UK or Ireland for Europeans) and students can work. However, there are also countries where students are allowed to work for a limited time of hours under a student visa (e.g. Australia and Canada for Europeans), and there are countries like the US where any kind of work is forbidden. If they are allowed to work, the customers of language courses get a triple status of student, tourist and worker.

The reasons for studying abroad are many. In the last decade, consequently the world crisis and the globalisation, on the top of the reasons to learn a language abroad there is the career progression.

$\square$ In 2016, the Economist Intelligence Unit (EIU) published a survey of young graduates to examine the role foreign experience plays in professional development. The survey comprised of 1,072 recent graduates and $72 \%$ of the respondent believed that taking a language course was essential for their job search (Greiner, 2017).

Career progression and experiencing a new culture are the main customer's motivations in this competitive market. The customer is historically an individual who comes from the upper middle class due the high cost of the course. People from the lower middle class are new profiles of customers that can access to the product thanks to funding programs activated by Governments.

\section{Self-funding and Government Sponsorships}


Customers in the sector have historically been part of the upper middle class. As every customer of luxury products, price was not of influence in the decision process. Customers' decision process is lately changed, especially after the 2008 crisis, and now they are price sensitive. Promotions are mostly activated to direct customers to destinations following the seasonality, but in the past promotions were almost inexistent. Courses were only self-funding before the activation by Governments of programs where students can access to grants for studying abroad.

Governments are now target audience for the companies in the sector. Grants are given to applicants in form of contract where usually is required to students to go abroad, improve their language skills and come back in the country to invest in the territory. Angola, Italy, Saudi Arabia are just few of the countries where the Government allocates every year a consistent amount of money for these programs. One of the main factors that give students access to the grant is the family income, and lower middle classes have more chance to get it.

The student profile has consequently changed and the lower middle class can now access to the product. Countries where this funding system has been activated are seen as the new potential customers because all social classes can get the most important skill to rule the global economy: English language.

\section{Trends and Influences in the Sector}

As every sector in the travel and tourism industry, the study abroad programs follow trends and are subjected to macroeconomics changes.

Destinations are chosen according to trends and to the advertisements audiences are exposed in their daily life. There are cities that are famous touristic destinations and they are favourite of the audiences.

Between course and destination, the second one is the starting point in the buyer decision. If it is not included in the offer, companies can lose the customer who will choose the competitor. Main competitors have schools in the most requested destinations and the proximity of touristic attractions and city centres influence the buyer decision.

The sector is sensible to macroeconomic and political decision as well. For example, the terrorist attacks happened in the last ten years (Lambin, 2002) have affected the market and redirect the flow of students from one destination to another.

The sector is sensible to monetary political trends too. Especially for English learners, moving abroad to the country means access to a different currency. The fluctuation of the currency is an important factor in the choice of the destination.

Destinations lose attractiveness when their currency is strong. Students avoid expensive destinations when the same experience can be offered in a more convenient place.

The United Kingdom has seen a decrease on arrival when the GBP was strong. After the Brexit referendum and the depreciation of the British Pound the country has become competitive again.

$\square$ Ireland is the only English speaking country where the currency is the same of other countries where English is not the first language. 
Having the Euro as currency make its competiveness stable, especially for EU students.

The political decisions have even effects to the attraction of destinations. International students need often a visa to study abroad. There are Governments that are open to accept international students and they are keen to release visas for educational purposes. When the Governors change, the rules and relationships between countries change as well and the numbers of visas released lower as a consequence of the increase of requirements the students are subjected to demonstrate.

After the election of Trump as president of the USA, the relationships with South and Central America, just to mention a few, has changed. This restrictive behaviour had a negative impact on the industry. Students and tourists are now sceptical to travel to the USA, visas refusals have increased and other destinations are now more appealing for these audiences.

In all the mentioned cases, the country economy is affected from the lower numbers of students that get in, and this has definitely impact on the tourism industry as well.

\section{Bibliography}

Arrigo, E. (2012). Alliances, Open Innovation and Outside-in Management, Symphonya. Emerging Issues in Management (symphonya.unimib.it), 2, 53-65.

http://dx.doi.org/10.4468/2012.2.05arrigo

Arrigo, E. (2009). Market-Driven Management, Global Competition and Corporate Responsibility, Symphonya. Emerging Issues in Management (symphonya.unimib.it), 1, 54-70. http://dx.doi.org/10.4468/2009.1.06arrigo

Baradello, C. S., Salazzaro, A. (2012). The Role of Imitation in Global High-Tech Product Development, Symphonya. Emerging Issues in Management (symphonya.unimib.it), 1, 57-71.

http://dx.doi.org/10.4468/2012.1.05baradello.salazzaro

Brondoni, S. M. (2016). Global Tourism Management. Mass, Experience and Sensations Tourism, Symphonya. Emerging Issues in Management (symphonya.unimib.it), 1, 7-24.

http://dx.doi.org/10.4468/2016.1.02brondoni

Brondoni, S. M. (2015). Global Networks, Outside-In Capabilities and Smart Innovation, Symphonya. Emerging Issues in Management (symphonya.unimib.it), 1, 6-21.

http://dx.doi.org/10.4468/2015.1.02brondoni

Brondoni, S. M. (2008). Market-Driven Management, Competitive Space and Global Networks, Symphonya. Emerging Issues in Management (symphonya.unimib.it), 1, 14-27.

http://dx.doi.org/10.4468/2008.1.02brondoni

Brondoni S. M. (2000-2001) Brand Policy and Brand Equity, Symphonya. Emerging Issues in Management (symphonya.unimib.it), 1, 5-25.

http://dx.doi.org/10.4468/2001.1.02brondoni

Codignola, F., Mariani, P. (2017). Location Attractiveness as a Major Factor in Museum Visitors' Choice and Satisfaction, Management Studies, Mar.-Apr., Vol. 5, (2), 75-90.

http://dx.doi.org/10.17265/2328-2185/2017.02.001 
Greiner, A. (2017), How Can English Benefit Your International Career?, Kaplan international English. https://www.kaplaninternational.com/blog/how-english-benefits-your-career

Icef Monitor (2016), 2.28 million abroad for language study in 2014, Icef Monitor.

http://monitor.icef.com/2016/04/2-28-million-abroad-for-language-study-in-2014/

Lambin, J. J. (2002). Strategic Marketing Revisited after September 11, Symphonya. Emerging Issues in Management (symphonya.unimib.it), 1, 7-27.

http://dx.doi.org/10.4468/2002.1.02lambin

Riboldazzi, S. (2005) Global Retailers and Competitive Customer Value, Symphonya. Emerging Issues in Management (symphonya.unimib.it), 2, 77-87.

http://dx.doi.org/10.4468/2005.2.07riboldazzi

Salvioni, D. M. (2016). Hotel Chains and the Sharing Economy in Global Tourism, Symphonya. Emerging Issues in Management (symphonya.unimib.it), 1, 31-44.

http://dx.doi.org/10.4468/2016.1.04salvioni 